\title{
Activities of institutional quality assurance cell of Bangabandhu Sheikh Mujib Medical University
}

\section{Md. Shafiqul Islam and Harasit Kumar Paul}

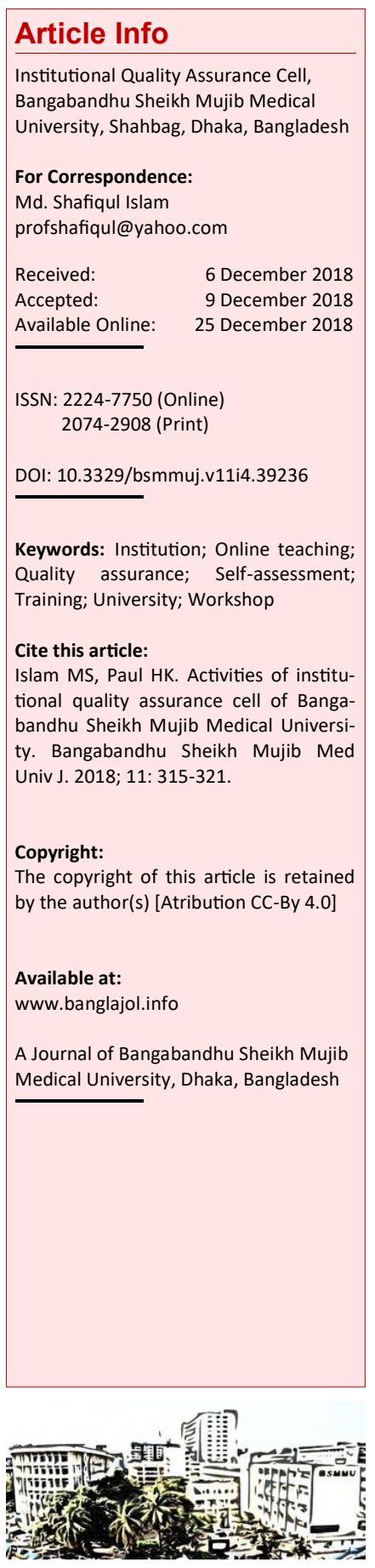

\begin{tabular}{l}
\hline Institutional Quality \\
Cell_ Assurance \\
\hline
\end{tabular}

The Quality Assurance Unit of the University Grants Commission, Bangladesh took initiatives to establish institutional quality assurance cell in 31 public and 38 private universities of the country in four rounds. In response, Bangabandhu Sheikh Mujib Medical University formed an institutional quality assurance cell in July 2015. It was a 3-year project started with the aim to promote the quality culture within the university.

During this period, the cell organized 62 trainings and workshops on various topics, coordinated and supervised self-assessment activities in 40 academic programs of the university. In total, 1211 faculty members, students, officers, nurses, and auxiliary staff were the participants.

\section{Workshops}

The cell organized 49 workshops on various topics.

Induction program: The first workshop on induction program was organized with a view to orient the faculties and representatives from the university and hospital administration on institutional quality assurance processes. The global perspective on quality assurance, reasons for the rapid growth of quality assurance practices and quality assurance agencies worldwide, quality assurance networks, quality in education, principles of internal quality assurance and external quality assurance were discussed.

Self-assessment report writing and financial management: Three workshops on self-assessment report writing and financial management were arranged. One was only on self-assessment report writing and two were on selfassessment report writing and financial management. Discussions were centered on a uniform reporting format for each of the departments. There were 12 chapters in the format. The first chapter was on the introduction, followed by 9 chapters on quality assurance areas selected by the Quality Assurance Unit of the University Grants Commission, Bangladesh. One chapter was on the strength, weakness, opportunity and threat (SWOT) analysis and the last one was on the conclusion, recommendation and improvement plan. In financial management part, the eligible expenditure under self-assessment fund, funding management between the institutional quality assurance cell and self-assessment committee, payments from the operating account and financial responsibilities of institutional quality assurance cell and departmental self-assessment committee were discussed.

Online teaching, exam and evaluation techniques: Three workshops were organized. Topics covered were the background of online education, essential technologies for online education, designing on-line courses, precondition for success in on-line education, technology infrastructures, technical and administrative supports, educational supports, skills of on-line teachers, tools for online learning, types of online assessment and advantages of on-line assessment.

National qualification framework: The Quality Assurance Unit of the University Grants Commission, Bangladesh has been working on formulating a national qualification framework. This is an effort to level the academic degrees available in Bangladesh into a single framework. A workshop was organized for preparing recommendations on 'How will the medical degrees be labeled in the national qualification framework?'

Post self-assessment improvement plan: Two workshops on this topic were held. There were discussions on proper writing of post selfassessment plan. The participants were the members of all program self-assessment committee.

Personal database development and maintenance: Three workshops were organized on personal data-base development and maintenance. Each teacher should have a personal data sheet. The IT department formulated a format of the personal data sheet. The discu- 


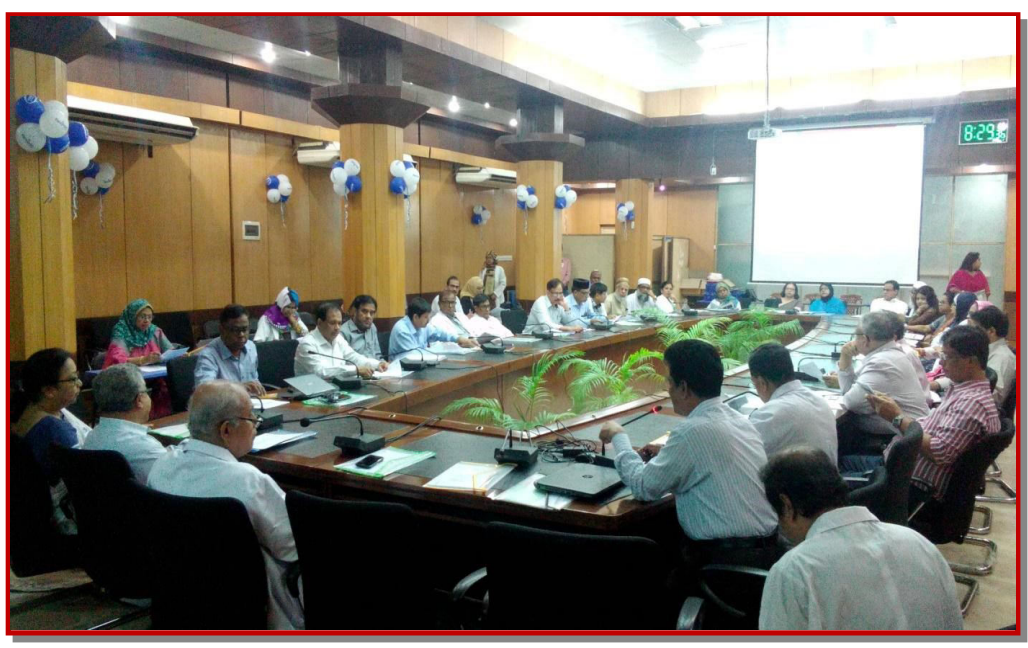

Figure 1: A view of the stakeholders workshop participated by the departmental chairpersons and university officials

ssion was centered on regular use and updating of the personal data sheet.

Good governance: Office management and financial management: Four workshops were organized. The discussion was centered on good governance, financial responsibilities, payments from operating accounts, cash basis accounting, books of account and supporting documents, bank account operation, petty cash management, bank reconciliation, petty cash reconciliation, general ledger reconciliation, month end ledger balancing, office management, building mindset, internal and external audit.

Review and modification of varsity rules, regulations and ordinances for good governance: Ten workshops were organized. The topics of the discussion were syndicate, academic council, university authority, disciplinary board, office attendance, leave rules, punishment and accreditation.

Development and management of result preparation and tabulation: One workshop was arranged. The areas covered were the activities before examinations, during examinations and after examinations; time management; record keeping; and issues related to confidentiality.

Question preparation: One workshop was organized on this topic. Bloom's taxonomy was discussed and was urged to set questions covering all of the aspects of cognitive domain like knowledge, understanding, applying, synthesizing, analyzing and evaluating. Questions covering the knowledge, understanding and applying areas are for assessment of lower order learning and questions covering synthesizing, analyzing and evaluating areas are for the assessment of higher-order learning.

Stakeholders workshop on quality assurance: Twelve work-shops were organized for the stakeholders (Figure 1). The stakeholders were the teachers, administrative staff, Medical Officers, students, Nurses and auxiliary staff.

Online academic management: One workshop was arranged on this topic. The discussion was centered on the online learning management system, online university management system, online registration, online leave application and processing, online pay bill submission, online availability of each and every departmental day/month/yearly activities.

Library services management: One workshop was arranged. The topics of discussion were the types of library, library manual, major activities, functions, accessioning, processing, circulation and membership.

University policy and strategy (act, rules and ordinances): Two workshops were organized. The discussion was centered on the historical perspective of higher education \& university, basic characters of university, university governance, importance of governance, legal frame, legal bodies \& their role, operationalization of the university, shared governance, role of leadership and internationalization.

Outcome-based curriculum: Three workshops were organized (Figure 2). The discussion was centered on the concept of outcome-based education, factors to be considered in outcome based education, benefits of outcome-based education, deficiencies of traditional education, curriculum design, curriculum mapping, Bloom's taxonomy, learning pyramid, program learning outcome, generic skill, graduate profile and assessment of learning outcome.

Curriculum format: The members of the external peer review team opined during the peer review process of each and every academic program to convert our present curriculum to outcome-based one. So, a workshop was organized to make a common format for the curriculum.

\section{Training}

During this period, the cell organized 13 training programs on various topics.

Self-assessment activity concepts, techniques and students learning outcomes: To orient the selfassessment activity concept members on selfassessment concepts, self-assessment techniques and techniques of assessing the students learning outcomes three training programs were organized. Emphasis was given on the assessment of an academic program. Self-assessment is a part of the internal quality assurance process. The Quality Assurance Unit of the University Grants Commission, Bangladesh selected nine criteria and 77 standards for self-assessment which were discussed. 


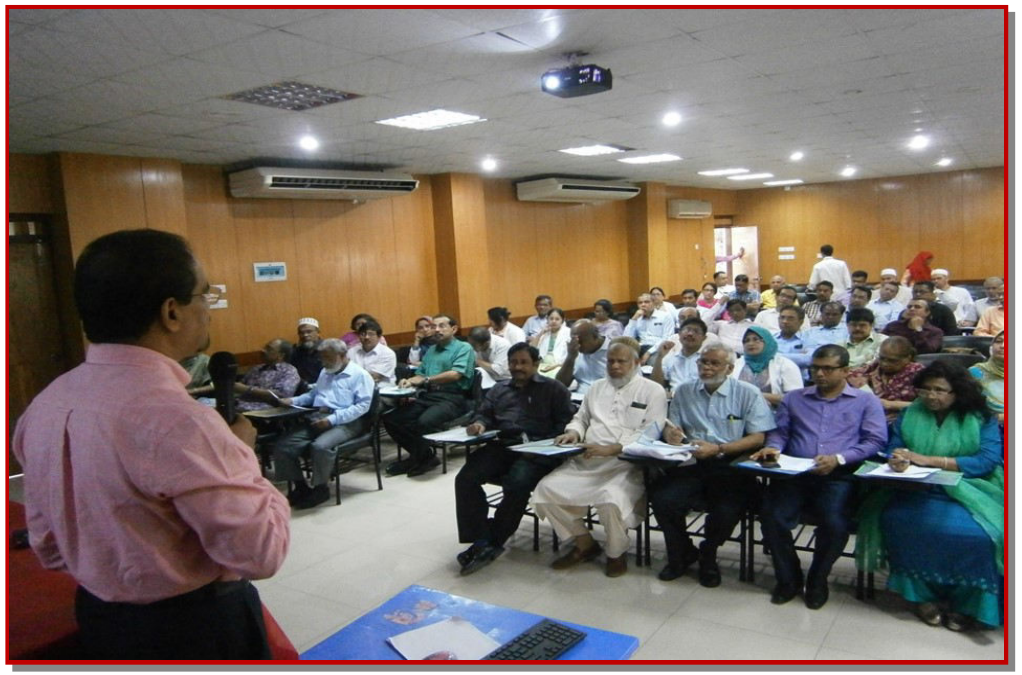

Figure 2: Foreign expert on outcome-based education

Pedagogy and metacognitive tools and techniques: Two training sessions were organized which include metacognition, component of metacognition, cognitive vs metacognitive strategies, instructional strategies, metacognitive process, traditional lecture, weaknesses of traditional lecture, interactive lecture and learning style were discussed.

Research methods, tools and techniques: Three training programs were arranged which include study design, descriptive vs analytical studies, observational vs experimental studies, crosssectional study, case-control study, randomized controlled trial, cohort study, sampling, randomization publication types, journals with impact factors, university ratings were discussed.

Curriculum concepts, models and development strategy: Three training programs were arranged. Topics covered different natures of curriculum, types of curriculum, principles of curriculum development, steps of curriculum development, issues in designing curriculum, basic points to consider in curriculum planning, components of curriculum, elements of specific learning objectives, lesson plan, structure of lesson plan, learning outcome and Bloom's taxonomy.

Role and responsibility and ethical principles: Two training programs were organized to orient the teachers regarding the roles, responsibilities and ethical principles. The discussions were centered on the concept of teaching and learning, qualities of a good teacher, students development, student assessment, total workload per week, criteria of a competent teacher/master teacher, teaching and research responsibilities of a teacher, responsibilities to the institution, responsibilities to the public and academic freedom.

\section{Self-assessment activities}

Out of 46 departments of this university, 40 fulfilled the criteria to be included under self-assessment processes. The self-assessment activities were run by a 3-membered self-assessment committee in each of the 40 departments. Out of 40 departments, the institutional quality assurance cell planned to conduct self-assessment in 12 academic programs in year-1, 18 programs in year-2 and 10 programs in year-3.

The self-assessment activities were done based on nine criteria. These were governance; curriculum content design \& review; student admission, progress and achievements; physical facilities; teaching-learning and assessment; student support services; staff and facilities; research and extension; process management and continuous improvement.

For each academic program, institutional quality assurance cell planned one workshop named 'Team building workshop' for customization of a predesigned questionnaire; conduction of a survey among stakeholders; preparation of self-assessment report; external peer review of self-assessment report and preparation of an improvement plan on the basis of recommendations made by the external peer review team and findings of self-assessment report. For self-assessment of academic programs, data were collected from stakeholders like employers, faculties, alumni, residents, non-academic staffs. Patients were included as stakeholders in the case of clinical departments. Out of 40 departments, 38 departments successfully completed. Two of the departments failed to complete their tasks.

\section{External peer review}

For external peer review, a team was constituted for each of the academic program reviewed. Each team consisted of three members. One member of the team was a foreign quality assurance expert, one member was a local quality assurance expert and one member was a subject expert. None of the team members was the university official. The external peer review team reviewed nine criteria of each academic program.

External peer review team had gone through the self-assessment report and had meeting with the management: Vice-chancellor, Deans, Chairpersons, Librarian. The team had meeting with the stakeholders like employers, faculties, alumni, residents, nonacademic staffs; audited documents and records that have in the department like exam procedures, minutes of meetings, list of academic staff members and their qualifications, list of 
Table I

Judgement given by the external peer reviewers

\begin{tabular}{|c|c|c|}
\hline Name of the departments & Final score & $\begin{array}{l}\text { Overall judge- } \\
\text { ment }\end{array}$ \\
\hline \multicolumn{3}{|l|}{ Faculty of Medicine } \\
\hline Cardiology & 36 & Very good \\
\hline Psychiatry & 36 & Very good \\
\hline Hepatology & 32 & Good \\
\hline Gastroenterology & 30 & Good \\
\hline Hematology & 33 & Good \\
\hline Internal Medicine & 37 & Very good \\
\hline Dermatology and Venereology & 31 & Good \\
\hline Transfusion Medicine & 30.5 & Good \\
\hline Physical Medicine & 32 & Good \\
\hline Oncology & 33 & Good \\
\hline Rheumatology & 32 & Good \\
\hline Nephrology & 36 & Very good \\
\hline \multicolumn{3}{|l|}{ Faculty of Basic Science and Paraclinical Science } \\
\hline Physiology & 36 & Very good \\
\hline Microbiology and Immunology & 31 & Good \\
\hline Virology & 38 & Very good \\
\hline Pathology & 33 & Good \\
\hline Laboratory Medicine & 31 & Good \\
\hline Biochemistry & 31.7 & Good \\
\hline \multicolumn{3}{|l|}{ Faculty of Pediatrics } \\
\hline Pediatric Nephrology & 34 & Good \\
\hline Pediatric Gastroenterology & 33 & Good \\
\hline Pediatrics & 32 & Good \\
\hline Neonatology & 33.5 & Good \\
\hline Pediatric Hematology and Oncology & 34 & Good \\
\hline \multicolumn{3}{|l|}{ Faculty of Surgery } \\
\hline Cardiac Surgery & 30 & Good \\
\hline Neurosurgery & 32.5 & Good \\
\hline $\begin{array}{l}\text { Anesthesia, Analgesia and Intensive Care } \\
\text { Medicine }\end{array}$ & 36 & Very good \\
\hline Otolaryngology & 31 & Good \\
\hline Pediatric Surgery & 37 & Very good \\
\hline Ophthalmology & 37 & Very good \\
\hline Radiology and Imaging & 30 & Good \\
\hline Orthopedic Surgery & 28 & Good \\
\hline Community Ophthalmology & 30.5 & Good \\
\hline Obstetrics and Gynecology & 33 & Good \\
\hline Urology & 38 & Very good \\
\hline Surgery & Incomplete & \\
\hline \multicolumn{3}{|l|}{ Faculty of Dentistry } \\
\hline Conservative Dentistry and Endodontics & 27 & Good \\
\hline Orthodontics & 32 & Good \\
\hline Oral and Maxillofacial Surgery & 31 & Good \\
\hline \multicolumn{3}{|l|}{ Faculty of Nursing } \\
\hline Graduate nursing & 26 & Good \\
\hline \multicolumn{3}{|l|}{ Faculty of Preventive and Social Medicine } \\
\hline Public health and informatics & Incomplete & \\
\hline
\end{tabular}

publications, syllabus \& curriculum, activities of committee of courses \& studies, sample of exam questions, sample of answer scripts, student attendance file/record, class schedule, course files, university organogram, admission test procedure, recruitment and promotion policy of teachers, handbook, lecture plan. The team visited faculties office room, library, out-patient and in-patient departments, laboratories, teaching and learning facilities, institutional quality assurance cell office, administrative office, examination center, university data center, patients records room, baby daycare center, sports facilities, transport facility, gymnasium, auditorium and cafeteria. The external peer review team also observed the classroom teaching.

Based on observations the following aspects were judged using the given rating scale. The numerical weight of rating scale was: 5-excellent, 4-very good, 3-good, 2-poor, 1-unsatisfactory. As per this rating scale, the minimum to maximum score for an academic program might ranged from 15 to 50 .

Thirty eight of our academic programs those have completed the self-assessment activities, obtained scores ranging from 26-38 (Table I). Twenty eight programs were ranked 'good' and got a score of 26 to 34 . Ten programs were ranked 'very good' and got a score of 36 to 38. The Urology and Virology departments got the highest score of 38 . Though the maximum score was 50 , none got a score above 38 .

After the review process, the external peer review team made their recommendations for improvement of the academic programs. We have got recommendations from the external peer review team of 38 academic programs. For each program, recommendations were made under each aspect reviewed.

\section{Recommendations}

The specific recommendations provided were based on the external peer review team's observations and interactions with the stakeholders and analysis of the self-assessment report and other documents provided by the department (Supplementary data). The self-assessment report itself had identified a number of areas for improvement together with weaknesses and challenges to achieve desired outcomes in teaching and learning and research. These recommendations provided will add value to the already identified areas for improvement in the self-assessment reports. There is a certain gap among the opinion of the current students, alumni and that of faculty members and the gap is evident in almost all the aspects covered in the survey.

\section{Acknowledgements}

This work was supported by the World Bank, Bangladesh. We 
acknowledge the help of the Quality Assurance Unit, University Grants Commission of Bangladesh; Higher education quality enhancement project (HEQEP), Ministry of education, Bangladesh; Quality assurance committee, Bangabandhu Sheikh Mujib Medical University, Bangladesh; Self-assessment committee of 40 departments, Bangabandhu Sheikh Mujib Medical University, Bangladesh. We also grateful to the team leaders of external peer review teams: Prof. Bholanath Dutta (Founder and President, MTC Global, Bangalore, India), Prof. Ramesh Vemuganti (MTC Global, Bangalore, India), Prof. S. Sanjeevi (Anna University, Chennai, India), Prof. Vikas Kumar (IT and Operations Management, Sharda University, U.P., India), Dr. M. Habibur Rahman (International Development Consultant, Learning Synergy, Ottawa, Canada), Dr. S. M. Mohamed Ismail (Former Vice Chancellor, South Eastern University of Sri Lanka), Prof. B. V. Babu (Former Vice Chancellor, Graphic Era University \& Galgotias University, Andhra Pradesh, India), Prof. Fauziah Ahmad (School of Civil Engineering, Universiti Sains Malaysia), Dr. Aunul Islam (DIC, Foreign QA Expert, UK), Dr. Singye Namgyel (Chief Executive Officer, Thuksey Research and Consultancy, Thimphu, Bhutan) and Prof. Kamatchi Nagendra (Consultant, Manjunatha Layout, India).

\section{References}

1. Self-assessment manual. 2nd ed. Quality Assurance Unit of the University Grants Commission, Ministry of Education, HEQEP, Bangladesh, 2016.

2. IQAC documents- documents related to workshops/trainings organized by the IQAC, Bangabandhu Sheikh Mujib Medical University, Dhaka, Bangladesh.

3. External peer review reports of various departments of Bangabandhu Sheikh Mujib Medical University, Dhaka, Bangladesh.

4. Project proposal for establishment of IQAC at Bangabandhu Sheikh Mujib Medical University, Dhaka, Bangladesh. 


\section{Recommendation}

\section{Criteria 1: Governance}

1. Daily schedule of the faculty members need to be more efficient and effective. It shall comprise student guidance, mentoring, counseling, teaching and research.

2. The department should set measurable and realistic key performance indicators. Facilitation should be provided towards the achievement of the key performance indicators.

3. Departmental documentation is reasonably maintained but is mainly conventional (manual). More electronic documentation is needed.

4. A formal student progress monitoring through quality circle meetings (sessional results) needs to be carried out.

5. A formal training on pedagogical methods needs to be given to the newly joined faculty members.

6. While academic staffs are given provision to improve their expertise from time to time, there is no such provision for non-academic staff development in the department.

7. All the university systems and processes should be automated by using a professional business intelligence-based learning management systems and enterprise resource planning systems.

8. While recruiting the faculty members, equal emphasis should be given for teaching ability along with service and research capabilities.

9. Incentives and awards are to be introduced for faculty members for their research publications in Journals with impact factors.

10. Annual appraisal system should be there.

11. Academic calendar of the department in line with that of the university needs to be prepared and circulated among the students and faculty members and should be strictly followed.

12. Non-practicing allowance system has to be started (may be on optional basis to start with) for faculty members, so that they can give more time to academics and research activities of the university.

13. There should be a policy of spending some portion of departmental income on research activities of the department.

14. Medical support for Nurses and Technologists should be enhanced.

15. Training on Waste disposal management needs to be imparted to the staff involved in this activity.

16. Bangabandhu Sheikh Mujib Medical University deserves differential salary structure as they also provide service to the society in addition to teaching and research activities.

17. Students should be involved in decision making processes by nominating them as members of various academic and administrative statutory bodies of the university.

\section{Criteria 2: Curriculum contents, design and review}

1. The curriculum has to be updated regularly using bench marking as it is very traditional as of now.

2. The department should consider some open elective courses for the students to develop their knowledge and skills in the field of their interest.

3. Course curriculum needs to be realigned to implement outcome-based education.

4. Faculty should be trained on concept and constituents of outcomebased education.

5. The current syllabus should be reviewed to convert into a complete curriculum and should include generic skills, analytical skills etc.

6. Credit system needs to be introduced and credit hours must be properly calculated and implemented by providing required number of lectures, lab experiments and clinical activities.
7. Teachers should receive training on curriculum design \& development, teaching pedagogy and medical education. This should be sustained and an ongoing process so as to ensure quality curriculum.

\section{Criteria 3: Student admission, progress and achievements}

1. Course files should be maintained by the faculty members for each and every course offered in a program of the department. The contents should include detailed lesson plan, records of student performance in various evaluation components, minutes of quality circle meetings, question papers and solutions of all the evaluation components, etc. to monitor the progress of students.

2. Students' recognition system (for excellence in certain fields or areas) is not in place but should be increased to encourage as many students as possible to do better in all undertakings.

3. Student progress should be monitored through structured mentoring system on regular basis and the faculty members should provide regular academic counseling to the students about their academic progress.

\section{Criteria 4: Physical facilities}

1. The space provided for the department needs to be substantially increased.

2. Various facilities and services of departments are spread across the university in various blocks (outpatient department, ward, faculty chambers, indoor service, classroom, etc.). It will be convenient and have a better control if all these facilities and services are accommodated in close vicinity.

3. Campus should be made completely residential by providing housing facility for students, faculty members and non-academic staff which enhances the learning ambience.

4. Class room ambience has to be improved by maintaining exclusiveness and orderliness.

5. All the faculty members should be provided with independent office space.

6. Skill lab facility (cadaver exposure) is to be established for students to ensure hands on experience on skill development and project \& research based learning (PBL \& RBL).

7. Proper seating and wash room facility needs to be provided for the patients who visit the departments.

8. To ensure and encourage extra- and co-curricular activities, various University level clubs and departments (music, dance, sports, photography, fashion, press, debate, etc.) should be established in the university.

\section{Criteria 5: Teaching, learning and assessment}

1. At the beginning of each block, a course handout with full lesson plan (for the duration of the course) should be made available to the students. The course handout should include course title, course code, aim \& objectives of the course, names of the instructors/faculty members, prescribed textbooks \& reference books in standard format, detailed lecture plan specifying lecture number, learning outcomes, topics covered in each lecture, etc.

2. The concept of credit-hour system needs to be understood complete with contact hours and additional notional hours of efforts students need to put in for earning credits.

3. Teaching should be made more interactive and student-centric to have experiential learning for the students.

4. Rubrics/marking criteria should be defined for assessment to ensure objectivity in the marking. These should also relate closely to the learning outcomes of the course Assessment and teaching strategies should be carefully aligned with ILOs.

5. Generalized policy in terms of weightage of continuous and formative assessment and marking scheme of the students need to be introduced. 


\section{Recommendation}

6. More emphasis on exposure to 'Emergency consultancy' for students to be given.

7. Various evaluation components such as quizzes, surprise quizzes, assignments, seminars, group discussions, group tasks, and class tests should be included in continuous assessment.

8. Memory based questions are to be avoided and questions based on thinking and logical skills are to be incorporated in the examinations to test the creativity.

9. The department should consider practicing peer observation.

10. $24 \times 7$ online anonymous student feedback systems should be introduced in the department.

11. Different inputs to slow, normal and fast learners to be provided.

12. Answer scripts are to be shown to the students and step-wise marks distribution needs to be explained to the students.

\section{Criteria 6: Student support services}

1. Seminar library with integrated library management system in the department needs to be established.

2. Seating capacity in the central library has to be increased.

3. Issue of books to the students in the library needs to be introduced.

4. Student sick room in the hall/hospital is to be established for resident students.

5. Transport facility needs to be improved for the students.

6. The University should consider incorporating co-curricular activities into the curriculum, thus making it compulsory for all students to engage in some sort of co-curricular activities during their studies.

7. Student mentoring system should be in place. Teachers should provide counseling to students, with a certain number of hours allocated for the purpose. Academic guidance and counseling should be formalized with proper documentation.

8. Thesis grant for resident students' needs to be substantially increased.

9. Feedback from Alumni should be taken on regular basis to improve the quality of educational facilities.

10. The effectiveness of the student support services should be assessed annually.

11. The facilities for the students to be involved in the community service needs substantial strengthening.

12. Career counseling and more emergency visits need to be practiced in the department.

13. University may build a career visioning center to motivate the students towards their work and achievement in their respective fields.

14. Alumni association at the department level needs to be registered for their active participation in the development of the department.

15. Formal system needs to be developed to receive feedback from all the stakeholders.

\section{Criteria 7: Staff and facilities}

1. Professional development of faculty members is required in the form of training or peer sharing both on teaching pedagogy and Outcome Based Education.

2. Man power (both for faculty members and non-teaching staff) needs to be increased in accordance with the number of students admitted.

3. The department should maintain and update the list of publications of the academic staff on regular basis.

4. Adequate training programs for the non-academic staff are needed to keep themselves with the current issues related to their job areas and to be prepared for multi-tasking.
5. University may establish a staff development center to enrich the knowledge and effectiveness of the staff.

6. Accommodation facilities for teaching and non-academic staff should be provided in the campus.

7. Transport facility should be provided to all the staff members.

8. Paternity leave provision may be introduced for male faculty and staff members by the university.

9. Sick beds are to be substantially increased and quality of patient bed is to be improved for staff in the hospital.

10. Emergency treatment facility is to be introduced.

11. Free vaccination facility is to be provided to all the staff members.

12. Medical facility to be extended to the family members of teaching and non-teaching staff by providing a health card for each employee of the university.

13. Provision for study leave with pay needs to be established for nonacademic staff.

\section{Criteria 8: Research and extension}

1. Structured research policy with financial support needs to be formulated to ensure that all faculties are engaged in some kind of research activity, the result of which should go back into the teaching and learning processes.

2. The faculty should hunt for external research grants from national and international sponsoring agencies.

3. Research component has to strengthen in the postgraduate programs.

4. Financial support needs to be increased to the faculty members for attending International conferences.

5. The extension activities are not visible at all in the department, where the entity should place emphasis.

6. There is a need to have a reward system for the teachers who contribute to quality research.

\section{Criteria 9: Process management and continuous improvemen}

1. Job descriptions for faculty members and non-academic staff need to be provided.

2. Service code of conduct needs to be established in the university.

3. There should be a paradigm shift from existing over emphasized end term examination system to continuous and internal examination system with relative grading.

4. The university may take initiative to review its existing policies and procedures, which are very important for better program management and quality assurance.

5. Grievance redressal systems for students and staffs should be in place and a formal committee for prevention of sexual harassment needs to be constituted.

6. The department should execute self-assessment periodically.

7. The institutional quality assurance cell needs to play a very important and prominent role in ensuring that the faculty members of the department are well-trained and well-versed in teachinglearning, pedagogy and assessment-related matters.

8. Training programs are to be arranged for non-academic staff in multi -tasking to sustain their interest and to break the monotony.

9. Training need to be imparted to administrative staff of the department for proper labeling, numbering, tabulating, and maintaining the documents/files.

10. Bangabandhu Sheikh Mujib Medical University, being a specialized hospital based university, should entertain only referred cases to have a control on number of patients to be treated. Otherwise, more manpower needs to be provided if the present situation of making it open to all generic cases is to be continued. 